\section{The Forest Manager's Entomological Dream ${ }^{1}$}

\author{
By KENNETH GRAHAM
}

"Was it a dream or a picture or reality?"

Faculty of Forestry,

University of British Columbia,

Vancouver, B.C.

ODC 945.4: 145.7

\section{Abstract}

Decision-making in insect pest management requires a large resource of information for predicting, evaluating and interpreting causes of insect aggressions, and funds of information on alternatives between no action and various courses of positive action. The task of searching out relevant information for these purposes is immensely complex, and relevance is difficult to evaluate when seen only in the short term context which clamors for "action now".

Research is conducted in two philosophically different ways. The more usual approach is technique-oriented and sifts extensively for the hidden truths of nature. Then the facts are surveyed for possible, and often unpredicted applications. Diverse motives spur an investigator on. Often it appears that he is unclear of the full relevance of his own effort in relation to the problem he hopes to solve. This is part of the price to be paid in the course of gaining factual revelations which are to be directly applicable to pest management, and for the information which assists other researchers in solving problems. The other approach in research reaches out to a speculated goal of manipulating nature in a specifically defined way. The obstacles are envisioned more clearly and attacked more narrowly and intensely. This is called "mission-oriented" research. It often involves more speculation and "intuition", circumventing broad exploration, but is capable of attaining some goals which would be scarcely attainable by the free-directional approach. Both philosophical approaches are complementary in solving problems.

There is some justification in assertions that

Article bosed on lecture in "Principles of Forestry and Wood Science" for students in the Humanities.

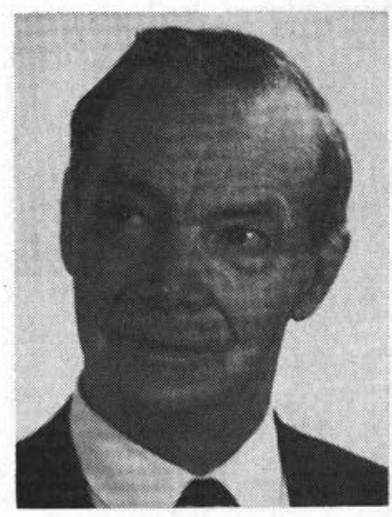

much of research lacks clear relevancy for forest insect pest management. Sometimes there appears no other reason for an undertaking than that it is a popular topic of the moment. However, the broad uncovering of new scientific territory in this way yields much that can be translated into action. Researchers might more often invest their talents in mission-oriented research which preconceives a possible workable goal more explicitly and clearly, using scientific speculation about the working of a facet of nature, then narrowing the experiments to test for workability.

\section{Résumé}

La raison d'être de l'entomologie forestière est qu'elle nous permet de comprendre, anticiper, et manipuler les entr'actions entre les insectes et les forêts. Les directeurs de forêts affirment que les entomologistes ne résolvent pas les problèmes. Ils croient que nous poursuivons des questions académiques, lesquelles ne conduisent pas de plus près aux solutions pour la protection des forêts.

Bien que le directeur de forêts n'ait pas une expérience très profonde pour juger la valeur des recherches il pourrait se demander si les entomologistes forestiers ont vraiment une vision claire de la convenance de leurs poursuites propres. L'on doit défendre la cause pour la poursuite de la recherche "pure", laquelle ne prétend pas à un usage pratique, et de la recherche "fondamentale", laquelle n'a pas d'objet déterminé quoique elle prétende à appartenir à un objectif pratique.

Des leçons se trouvent dans des travaux de plusieurs investigateurs américains qui poursuivent ce qu'on appelle la recherche "mission oriented" la caractéristique de laquelle est la création d'une idée bien considérée concernant un but possible 
selon la prédiction théorétique. Ensuite l'on recherche seulement les problèmes scientifiques qui sont clairement des obstacles.

L'auteur indique aussi que les chercheurs biologiques emploieraient la spéculation scientifique plus souvent pour l'exploration de phénomènes biologiques. Le procédé est plus intuitif que scientifiquement rigoureux, et l'épreuve de sa validité est pragmatique. Si une hypothèse est juste, des résultats certains doivent s'ensuivre. Ce procédé peut faciliter l'acquisition de l'objectif avec économie de temps et de labeur.

L'auteur employait la méthode spéculative pour rechercher les causes de la production des facteurs chimiques qui attirent les bostryches champignonneurs vers les troncs d'arbres. L'hypothèse fut avancée que le facteur commun pour toutes les conconstances qui aboutissent à la propriété d'attraction vers l'arbre pour les coléoptères doit être la stagnation du gaz pour la respiration du processus métabolique dans le bois. Encore une fois l'auteur postulait que le déclin d'oxygène valable résultait en substitution du métabolisme fermentatif au lieu du métabolisme oxidatif. Par conséquence des produits nouveaux se développent constituant des facteurs attractifs. Supposant que l'hypothèse soit juste, l'auteur trouve que le bois exhibe une attraction après les 24 heures d'état anaérobique. Maintenant l'on peut percevoir un moyen théorétique pour manipuler les facteurs biochimiques causatifs dans les troncs de l'arbre: c'est la "mission".

\section{The Frame of Reference}

For million of years before Mankind came on the scene, Nature's ancient foresters, the insects, presided over the birth, life, and death of forests. They remained the unchallenged masters among the animal forms which influenced the establishment, growth, ecological structure, and succession of forests. Now modern Man, undertaking to manage forests according to his own rules, has entered an arena of combat against these diminutive but prolific and ecologically stubborn foes. He must constantly take measure of their strength. He must make decisions as to when he should do battle with them. He must know what to do, and possess the technical means to do so. The field of endeavor dealing with these problems is what we understand by the term "forest entomology". Even though the subject may exist as a facet of ecology in the field of pure biology, with no other purpose than knowledge for its own sake, its main frame of reference is forest management, and thus the protection of forests. In this latter context the question is: How is research conducted to provide answers to protection from insects? What kind of research is relevant?

Relevance can best be understood in relation to purpose. In forest entomology the purpose is to understand, anticipate and manipulate the interactions between insects and forests. We must understand the ecological mechanisms influencing insect populations. There must be yardsticks of measure- ment: How else can one forecast or assess the numerical strength of the foe, evaluate the impact of forest environments on him, or his impact on forests? How else can one decide when and where to take action? Weaknesses in his physiological and ecological armor must be searched out. Only then can we match wits with these "silent saboteurs".

\section{Diversity of Information}

It has been asserted by forest managers that forest entomologists are in an ivory tower, collecting all sorts of information which falls short of the needs of managers. They contend that despite the research explosion and literature fall-out, some of our worst pest problems remain unsolved. The questions then are: How much justification is there to be critical of the slow progress? What is the magnitude of the task to find useful applications? What are the processes by which answers are found?

Picture the forest manager thumbing through stacks of recent journals and government publications dealing with forest entomology. He reads about the Blasted Bast-Eating Bark Beetle which has plagued the industry for years. His mind reels at the vast array of information about this insect. It seems that many academic observations have been made merely on the excuse that the Blasted Bast-Eating Bark Beetle is a menace to timber. There are descriptions of its microscopic anatomy, its ancestry, attack habits, and its love life. It has been measured and weighed and dissected. It has been heated and frozen, irradiated, poisoned, and bled. Its populations have been sampled, computerized, and life-tabled. Its occurrence and numbers have been correlated with weather and forest types, and victimized trees have been eyeballed for indicators of weakness, and analysed for resins, resin pressures, starches, tannins, and root rots. There are works on the losses caused by this pest, and theories as to why it likes one tree and not another, and why it has fat years and lean years. Various measures have been proposed for dealing with it by logging and spraying, sterilizing its males, or providing housing for woodpeckers. Still the pest defies easy control. Exhausted, the forest manager falls asleep and into a troubled dream.

\section{Diversity of Means to an End}

In his dream, our forest manager searched through the literature on the Blasted Bast-Eating Bark Beetle to discover what motivated entomologists to find out this assorted information. He found it filed under various headings. One large file was labeled: "Let's Quantify It". It seemed that whenever researchers didn't know what else to do with a problem they took measurements: numbers, sizes, lengths of whiskers .... It followed that numerical differences and variations indicated that something was, or had been, happening. If something had been happening, there must have been a cause. So, from piles of associated data, correlations were computed statistically. Dreaming on, our forest manager noted that 
many of the correlations had no meaning because they lacked a discriminating theory. This type of rereach had provided years of employment for some entomologists proving that the correlations were meaningful, and for others proving that they were not. In keeping with the times, probabilistic models had been constructed which hung precariously upon variables and unpredictables. Then Woodley and Whiffenspoofer contributed formulae whose numerical values for "constants" were never constant. When empiricism joined hands with mathematics some strange conclusions emerged. Thus Crowfoot had eyeballed his data, decided what they meant, chose a formula convenient to fit his belief, and argued the proof of his case on the grounds that the data conformed to his formula! More credible hypotheses and mathematical descriptions had been totally ignored.

In his somnolent state our dreamer seemed to know that quantification of data had constitued a great forward step in research methodology. It had contributed much to the evaluation of natural phenomena, the appraisal of Man's influences on nature, and effective designs of experiments. However, preoccupation with quantification seemed to have channeled disproportionately more effort into enlarging the inventory of "How much and how many?" than into philosophical elucidation of "Why?". When the "Why's" were not understood, foresters might undertake salvage, evaluate losses, or revise inventories, but seldom manipulate the causes of damage effectively.

Our forest manager discovered another file with the title: "It Seemed a Good Idea". In it he came across papers whose reason for being seemed merely that the particular angle of study hadn't been thought up before. They were presented on the grounds that someone might find a use for them. One paper by Bogmeier was entitled: "Hydrogen Ion Concentration Changes in the Sap of Trees Attacked by the Blasted Bast-Eating Bark Beetle". It turned out that Bogmeier liked $\mathrm{pH}$ meters: he had joined the ranks of both the "Gadgeteers" and the "New-Model-a-Year" researchers. Accordingly every year he had published such papers as: "Further Contributions on the $\mathrm{pH}$ of Bark Attacked by the B B E B B." He hadn't quite known why this would be useful, but felt intuitively that he was doing his bit in the campaign against the B B E B B.

There was a file entitled "Bandwagoneering". It contained papers that followed popular lines of pursuit favored during different eras. So there were papers on temperature and development, population sampling, life-tables, tree-risk-ratings, oleoresin exudation pressures, pheromones, attractants, insecticide miracles, and the insecticide menace. Various authors in turn had their own popular idea of entomological salvation.

The frontier of knowledge had been pushing ahead along a broad irregular front within the frame of reference of the B B E B B as a major pest. Meanwhile other contributions were being made to knowledge of the Yellow Bellied Spittle Bug ( $Y$ B S B), the Bulge-Bottomed Boom Beetle (B B B B), and a new Rare Rotten Log Borer ( R R L B).

Some works dealing with methods of combat dealt with "New Variations on an Old Theme". So there were papers by Fearless Fuddledick on "A New War Gas Effective Against the Spruce Needle Chomper". It seemed that ordinary pesticides applied to forests killed fish in the rivers and lakes. The new product was much more compatible with fish. The only problem was that operators had to dress up in a rubber suit to handle it. Oh yes, and it was even more deadly to birds!

In his troubled dream the forest manager noted that it had taken the efforts of many researchers to develop even some interim methods of pest management. To him the process was maddeningly slow, and much of the work seemed unrelated to the stated purpose of pest control. Accustomed as he was to decisive action, he was frustrated by the uncertainties, indecisions, and inadequacy of methods relating to pest management. Entomological researchers appeared to him like orb-spinning spiders on LSD, obsessed with the construction of a beautiful web attended to in the most infinite detail. It seemed that there was more of tactics than of strategy in research as problems were studied piecemeal, and he even wondered whether researchers always understood the full implications of their own findings.

His subconscious thoughts reminded him that the researcher himself was not entirely to blame for piecemeal research. Some investigators had become "gun shy" of administrators and politicians who exerted the pressures of expediency to do "something practical now" and "publish or perish". He tried to forget how industry itself sometimes had delayed progress when they refused to acknowledge that they had any insect problems, if they could sweep losses under the carpet by claiming tax exemptions, reduction in stumpage dues, or other business devices. This had been a special temptation for private operators on government-owned land. But when they owned the timber land themselves - Oh Boy!

\section{Pure Versus Applied Research}

In his dream, our forest manager came upon two groups of biologists in a heated argument. One group was spotted, and the other striped. The spotted ones called themselves "pure" researchers. They maintained that theirs were the only contributions of significance, because they sought knowledge for its own sake, unhampered by the constraints imposed by the demand for application. They regarded the work of their striped confreres, who called themselves "applied biologists", as ad hoc, terminal, and dirtied by the dollar sign. But even among themselves the spotted biologists wore different sizes of spots. Those with the smallest spots called themselves "Molecular Biologists" who worked at the ultimate level of refinement. It seemed that they looked down on lower strata of their kind, referring to the ecologists who worked with nature at the ecosystem level as "goat watch- 
ers". Then there was a group of mathematical modelists who were looked on with awe by everyone else because they had mastered a language which no one else quite understood.

\section{Dream or Reality?}

Drenched in perspiration, the forest manager awoke. Had this really been a dream or was it reality? Somehow he couldn't escape the feeling that it was indeed a picture of reality. The stories told by the published papers convinced him.

Much of what appeared in the dream has a suspicious resemblance to reality: the motives, perspectives, and attitudes in research. Massive programs of research operate with the subtlety of a tractor, under the assurance that something new will inevitably be unearthed, or that old findings will be reinforced. Like the "mills of God", the mills of research grind slowly and they grind exceeding small. This massive onslaught by research might be termed "free-directional". It is often largely technique-oriented. Speculative philosophy is negligible. Applications are sought after new ground is uncovered. This analytical approach of dissecting nature is scientifically respectable, productive of much that is directly useful, and always safe for a publication.

The dispute between the "pure" and "applied" reseacher is no dream. There have been university departments in which the pure researchers looked suspiciously, even disdainfully, on applied researchers as though a goal of application is scientifically restrictive, and about as respectable as syphilis. Restrictively, the purist denies himself the unique motivations which inspire the applied researcher to probe into special facets of nature. He denies himself the pragmatic test of proof inherent in the tangible demonstration that his predictions and discoveries really work when translated into application. The truth is that the different approaches to research make different contributions. But pure research does not provide all of the basic foundations needed for application. So the applied researcher often must pursue basic research which is no different from pure research except that it has a motive of laying groundwork for a specific intention.

\section{Mission-Oriented Research and Scientific Speculation}

Contrasting with the bulldozer approach to discovery, another method consists of defining a specific objective by speculating about a new means of manipulating nature. Specific requirements of knowledge for this goal are then clearly defined and researched, and specific obstacles of ignorance are forecast and removed by research until the envisioned goal is reached. This is referred to as "missionoriented" research. It is not a substitute for the bulldozer approach, but has peculiar advantages for the solving of certain problems.

One admirable illustration of mission-oriented research is exemplified in the work of Dr. Carl E.
Crisp and associates at the U.S. Forest Service Experiment Station in Berkeley, California (U.S.F.S. 1968). They defined their mission as the designing of a molecule which would penetrate foliage of a tree, split off a part of its molecule to travel with the sugars, and concentrate at the feeding sites of insects. As it enters the target insect it will become toxic, but if it enters a bird or mammal it will split into harmless fragments. By this means only noxious insects would receive toxic doses. Such a mission could not be approached by the usual process of massive exploration. In the process, exciting facets of nature are disclosed which might remain hidden to the pure-researcher who lacks the motives to pursue the same objectives.

Let us examine another type of problem which is proving amenable to a mission-oriented approach. This problem exists because people dislike holes in their woodwork. Motivational researchers have been unable to persuade buyers that lumber with genuine bug-holes is worth more. It is not easy to convince the anxious housewife that those holes won't have little things crawling out of them when guests arrive. Exporters cannot convince overseas buyers that a few of our species of insects in their country would make a nice contribution to their insect fauna.

The defect in question appears as little round holes edged in black. They are called "pinholes" or "shotholes", and look like the work of a triggerhappy bird hunter. But these are not instant holes. They were made by hard-working insects called ambrosia beetles, which set up residence in the green log before it reached the mill. The damage causes a pyramid of problems in grade and price and marketability of products, costly delays in clearance of shiploads of lumber, and other annoyances. The repersussions filter back to the mills, and ultimately the log supplier.

The standard methods used to protect timber from attack by ambrosia beetles necessitate inconvenient changes in operational practices, and objectionable applications of pesticides. There are attendant problems in pollution of water where logs are treated. Fish are killed, or their polluted flesh ends up on your dinner plate. Tests are continually going on with new and "safer" pesticides. This may provide an interim improvement in methods for protecting logs, but so far, the value of the chemicals depends on their poisonous properties.

It has been proposed by some investigators that it might be possible to modify a tree internally by a chemical injection to render it unpalatable to these insects. It is believed that if such a treatment can be found, the technical obstacles can be surmounted within reasonable economic limits. If the log can be modified internally the protection would be more dependable than a surface coating. Now, how do we go about searching for an answer?

First we accept the idea that the tree is going to die by harvesting, if not by the treatment. Therefore we are not limited by concern as to whether the treatment kills the tree by chemical or mechanical applications.

One might achieve the mission by applying one 
of a number of different tactics. Firstly, one might try shooting trees full of different kinds of insecticides, but then we are trying to avoid pesticides. Secondly, one might try soaking the logs full of the smelliest repellents we know. The problem is that substances which repel humans do not necessarily repel insects. Nevertheless the development of repellents through basic research is still an open possibility. Thirdly, one might empirically test all 38,000 chemicals which are listed for sale in the world. One might find an answer this way - if one lived long enough! However, the theoretically required agent may not yet exist, and the trials might not even contribute clues as to requirements. A fourth approach might be to modify the log with substances known to be general poisons for trees. Thus far the observed effect is acceleration toward attractancy. A fifth approach, scientifically respectable, would be to make an exhaustive analysis of all constituents and processes peculiar to the insect-susseptible tree, and then search for means of manipulation. This approach is, however, blind, and prodigal of effort.

In this laboratory we introduced scientific speculation into our methodology in order to narrow the search. Applying concepts of biochemistry, we constructed an hypothesis about the mechanism of attractancy formation in a tree. This then pointed the way to specific means of suppressing it. How does one go about this?

First let us see what feature suggests itself as the common key to all conditions leading to attractancy in a log. It matters little whether the tree is felled, defoliated, or poisoned, or whether its roots are flooded, drought-stressed, or suffocated by soil compaction: the result is attractancy of the wood to the beetles. The common feature? Stagnation! Stagnation of the sapstream and its partner, the gas stream. What then does this signify? The gas stream contains oxygen, and in a living system, oxygen performs in the role of metabolic scavenger for the hydrogen mobilized in energy transfer processes. The ray parenchyma cells in the wood are constituted to demand oxygen. Stagnation would lead to oxygen deficiency. Biochemically, this condition should induce metabolic fermentation, with formation of alcohol and other products foreign to the healthy tree. If this be so, the assumptions can be tested by experiment. Voilà! Attractancy does indeed form within a few hours after oxygen is experimentally exhausted from fresh sapwood (Graham 1968). Thus by this single experiment, arrived at by speculation, the trail toward a "mission" is at once delineated: we are in search of a suppressant for metabolic fermentation. Biochemical theory suggests various means of achieving this. Already a collaborative study between ourselves and $\mathrm{Dr}$. R. W. Kennedy and Mr. H. A. Moeck of the Forest Products Laboratory, Canada Department of Fisheries and Forestry, is confirming this capability.

\section{References}

U.S. FOREST SERVICE. 1968. "Designing a super molecule a symplastic systemic insecticide". U.S.F.S. Pacific Southwest Forest \& Range Expt. Sta. News Bul. "What's new in research". $4 \mathrm{pp}$.
It is intriguing that the conformity of results with predictions has not yet confirmed the hypothesis. It has merely established a high degree of credibility. If other predictions from the hypothesis come true, the credibility will be reinforced. Objective proof is another problem. In the meantime the hypothesis is "working" as a predictive instrument, and we may expect "spin-off" benefits in the form of increased understanding of living trees in relation to their environment. For example, in this laboratory (unpublished data) we have shown that oxygen depletion in phloem can be a factor in susceptibility of trees to barkbeetles.

In this instance, scientific speculation is proving to be a productive instrument. It has been more productive for the effort expended than a free-directional shotgun approach which discharges in a wide pattern, followed up by a post-mortem examination to discover what kind of pigeons have been bagged to put in the cooking pot. It is somewhat akin to the method of the medical clinician who speculates about a cause, and argues credibility for his diagnosis by the fact that his treatment "works".

Whichever way one chooses to approach research, discretion is paramount. Even respect for good scientific technique will not compensate for a bad hypothesis or a poorly chosen undertaking. We are reminded of the story of the fellow who had trained a flea to jump on command. Knowing that sound-production in some insects involves the legs, he adventurously thought it credible that sound reception also might reside in the legs. This he wanted to prove for fleas. Meticulously he removed legs one pair at a time, thus dutifully paying homage to the preservation of the insect's appendicular symmetry. After removal of the front pair of legs the flea still jumped on command. He then removed the second pair of legs, and on the command "jump" the flea again obediently jumped. Being a good entomologist, the fellow searched for a third pair of legs which entomological theory said he should find. Deftly he disencumbered the flea of its remaining pair of legs. On the command: "Jump!" the flea just sat there. Being knowledgeable on statistics, the fellow knew he should replicate his tests, so repeated the command. Still no response. Carefully he recorded in his notebook: "When the hind legs are removed the flea becomes deaf."

\section{Acknowledgments}

I extend thanks to Prof. J. V. Thirgood for suggesting submission of this lecture for publication. I am deeply indebted to my wife, Ruth for her continued inspiration and much help in shaping thoughts and expressions in the manuscript. I wish to express sincere thanks to Mrs. Michele Neish and Mrs. Dona MacLellan for their care in typing the manuscript through several revisions, and to Mrs. Neish for her kindness in editing the resume in French.

GRAHAM, K. 1968. "Anaerobic induction of primary chemical attractancy for ambrosia beetles". Can. J. Zool. 46 (5): $905-908$. 